\title{
WYKORZYSTANIE SPEKTROMETRII IMPEDANCYJNEJ DO MONITOROWANIA PRZEPŁYWU FILTRACYJNEGO PRZEZ NASYPY HYDROTECHNICZNE
}

\author{
Andrzej Gruchot ${ }^{1 凶}$, Tymoteusz Zydroń1, Jana Pařilková2, Zbyněk Zachoval ${ }^{2}$, \\ Mariusz Cholewa', Karolina Koś'
}

'Wydział Inżynierii Środowiska i Geodezji, Uniwersytet Rolniczy w Krakowie, Kraków

${ }^{2}$ Faculty of Civil Engineering, Brno University of Technology, Czech Republic

\begin{abstract}
STRESZCZENIE
Jeden z ważniejszych problemów w ocenie stanu technicznego ziemnych budowli hydrotechnicznych dotyczy obserwacji procesu filtracji wody i analizy możliwości powstania niekorzystnych zjawisk z nim związanych. Celem przeprowadzonych badań była ocena przydatności spektrometrii impedancyjnej (EIS - Electrical Impedance Spectroscopy) do obserwacji przebiegu procesu filtracji wody przez korpus obwałowania ziemnego. Badania przeprowadzono w korycie hydraulicznym na modelu nasypu obwałowania wykonanego z piasku grubego pylastego. Przepływ filtracyjny wywoływany był poprzez kilkustopniowe podnoszenie i opuszczanie wody w korycie hydraulicznym. Pomiary wartości oporności gruntu odniesiono do rejestrowanego w sposób automatyczny poziomu piezometrycznego wody. Uzyskane wyniki badań wykazały istotną zbieżność zmian oporności gruntu ze zmianami położenia poziomu zwierciadła wody filtracyjnej mierzonymi w piezometrze.
\end{abstract}

Słowa kluczowe: spektrometria impedancyjna, filtracja, budowla ziemna

\section{WSTĘP}

Ocena stanu technicznego ziemnych budowli hydrotechnicznych wymaga prognozy procesu filtracji i analizy możliwości powstania zjawisk z nim związanych. Bednarczyk, Bolt i Mackiewicz (2009) wskazuja, że zmiany struktury gruntu spowodowane filtracją wody stanowią ponad $35 \%$ awarii obiektów hydrotechnicznych. Zatem obserwacje rzeczywistych strumieni filtracji w zaporach ziemnych pozwalają wskazać miejsca w korpusie zapory, gdzie proces filtracji może zagrażać bezpieczeństwu budowli (Pisarczyk, 2001; Molski, 2010). Należy zauważyć, że właściwa ocena zjawisk filtracyjnych przez ośrodek porowy, jakim są nasypy ziemne, jest jednym z trudniejszych zagadnień w mechanice gruntów. Wynika to z problemu właściwego oszacowania współczynnika filtracji, który opisuje zjawiska filtracji przez grunty mineralne (Chalfen i Kamińska, 2011).

Jednym ze sposobów kontroli przepływu wody przez hydrotechniczne nasypy ziemne jest metoda oparta na spektrometrii impedancyjnej. Metoda ta polega na pomiarze liniowej, elektrycznej odpowiedzi badanego materiału pobudzonego małym sygnałem elektromagnetycznym w szerokim zakresie częstotliwości. Metoda ta pozwala na kontrolę przepływu wody gruntowej lub filtracyjnej, a także na identyfikację obszarów niejednorodnych pod względem porowatości gruntu (Pařilková i Pařilek, 2008, 2015; Pařilková, Zachoval, Pařilek i Frankova, 2015). Wyniki

$\otimes_{\text {rmgrucho@cyf-kr.edu.pl }}$ 
pomiarów zależą od zewnętrznych czynników, takich jak temperatura wody i gruntu, wilgotność powietrza i gruntu oraz ciśnienie atmosferyczne (Pařilková i Pařilek, 2008; Yanev, Farhi, Draganova i Ionova, 2014; Gruchot, Zydroń, Cholewa i Koś, 2016).

Celem badań było określenie możliwości zastosowania spektrometrii impedancyjnej (EIS - Electrical Impedance Spectroscopy) do oceny przebiegu procesu filtracji wody przez korpus obwałowania ziemnego. $\mathrm{W}$ pracy porównano zmiany poziomu wody w piezometrze w modelu nasypu obwałowania $\mathrm{z}$ wartościami rezystancji gruntu i obliczeniami filtracji nieustalonej metodą elementów skończonych.

\section{ZAKRES I METODY BADAŃ}

Badania przeprowadzono w korycie hydraulicznym Katedry Inżynierii Wodnej i Geotechniki Uniwersytetu Rolniczego w Krakowie. W korycie wykonano model nasypu obwałowania z piasku grubego pylastego o długości podstawy i korony odpowiednio 2,0 i $0,5 \mathrm{~m}$, szerokości $1,0 \mathrm{~m}$ i wysokości $0,6 \mathrm{~m}$ oraz nachyleniu skarpy odwodnej 1:1,5 i odpowietrznej 1:1 (rys. 1). Nasyp wykonano na warstwie iłu o grubości $4 \mathrm{~cm}$, która stanowiła warstwę nieprzepuszczalną zapobiegająca przed filtracją przydenną. Uszczelnienie zastosowano również na ścianach bocznych koryta w postaci pionowych pasków iłu. Zainstalowane piezometry za pomocą czujników elektronicznych umieszczonych $\mathrm{w}$ ich podstawie mierzyły $\mathrm{w}$ sposób ciągły zmiany poziomu wody na stanowisku górnym (piezometr P1), dolnym (piezometr P6) oraz wody filtracyjnej (piezometry P3 i P4).

Podnoszenie i obniżanie wody w korycie hydraulicznym przeprowadzono $\mathrm{w}$ dwóch etapach. W pierwszym etapie piętrzenie wody realizowano od strony skarpy odwodnej w kilku stopniach przez 36 dób. W drugim etapie piętrzenie wody realizowano zarówno po stronie odwodnej, jak i odpowietrznej modelu również przez 36 dób. Zmiany poziomu piętrzenia wody w trakcie trwania badań przedstawiono na rysunku 2.

Podstawowe właściwości fizyczne oraz parametry zagęszczalności gruntu nasypu oznaczono metodami standardowymi. Skład uziarnienia oznaczono metodą łączoną, tj. sitową na mokro dla ziaren powyżej $0,063 \mathrm{~mm}$ i areometryczną dla cząstek mniejszych. Wilgotność optymalną i maksymalną gęstość objętościową szkieletu oznaczono $\mathrm{w}$ aparacie Proctora w cylindrze o objętości $2,2 \mathrm{dm}^{3}$ przy energii zagęszczania $0,59 \mathrm{~J} \cdot \mathrm{cm}^{-3}$. Współczynnik filtracji określono w edometrze na materiale o uziarnieniu mniejszym niż $4 \mathrm{~mm}$ przy przepływie wody od dołu do góry.

Metoda EIS służy do pomiaru charakterystyki elektrycznej badanego gruntu w postaci złożonej, tj. rezystancji - oporu elektrycznego $(R)$ i reaktancji $(X)$ w zakresie częstotliwości sygnału zasilającego. Rezystancja jest oporem rzeczywistym (czynnym) w obwodzie elektrycznym i jest to tzw. oporność elektryczna, która

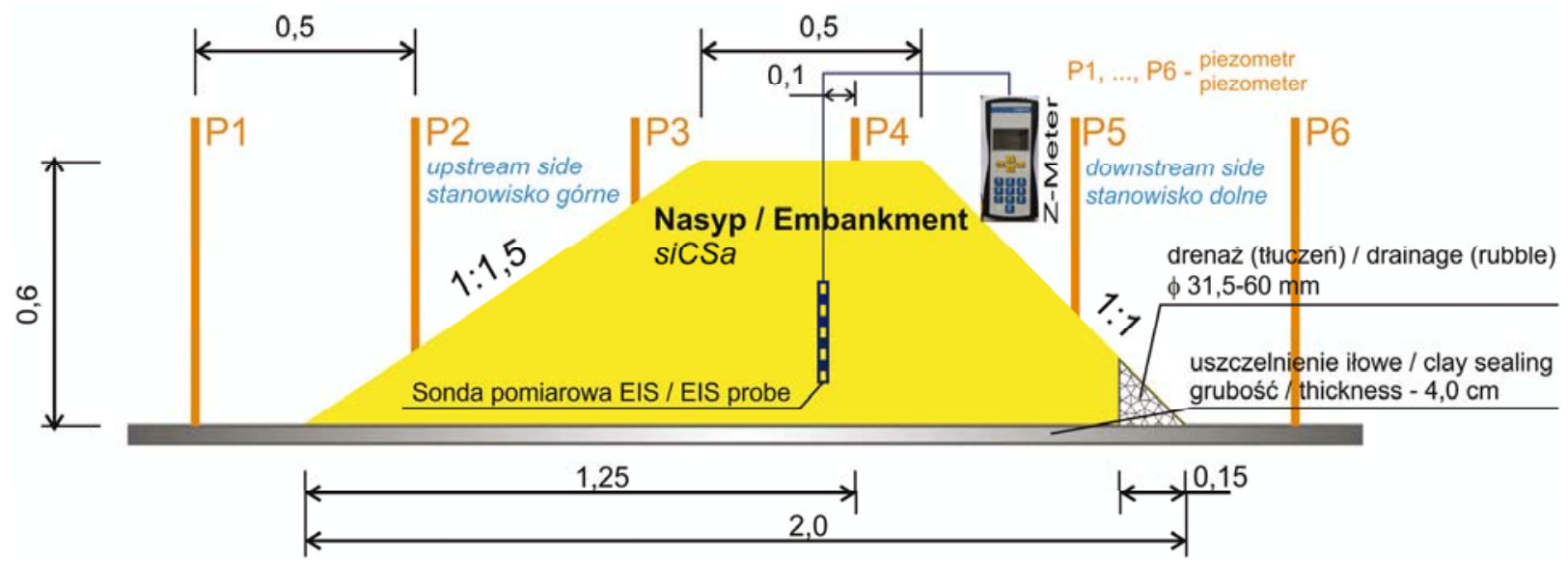

Rys. 1. Przekrój poprzeczy modelu obwałowania (wymiary w m)

Fig. 1. The cross section of the embankment model (dimensions in $\mathrm{m}$ ) 
Gruchot, A., Zydroń, T., Pařilková, J., Zachoval, Z., Cholewa, M. i Koś. K. (2018). Wykorzystanie spektrometrii impedancyjnej do monitorowania przepływu filtracyjnego przez nasypy hydrotechniczne. Acta Sci. Pol. Architectura, 17 (1), 55-65. doi: 10.22630/ ASPA.2018.17.1.6

a

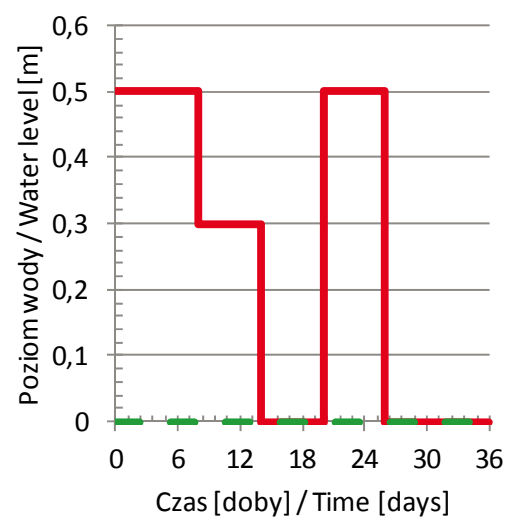

b

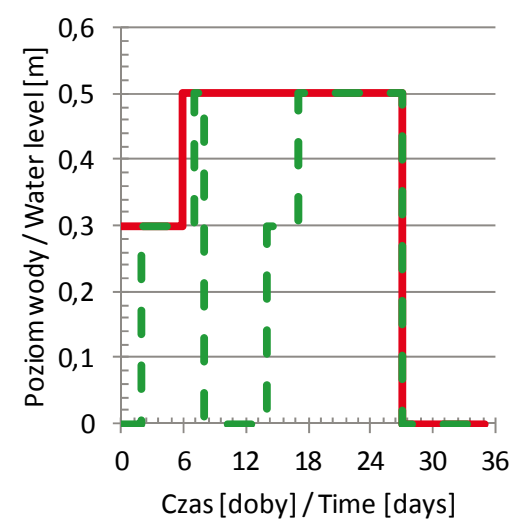

poziom wody górnej / upstream side water level

- poziom wody dolnej / downstream side water level

Rys. 2. Zmiany poziomu piętrzenia wody górnej i dolnej: $\mathrm{a}-\mathrm{w}$ pierwszym etapie badań, $\mathrm{b}-\mathrm{w}$ drugim etapie badań

Fig. 2. Changes in the level of damming the upstream side and downstream side water: $a$ - in the first stage of the tests, $\mathrm{b}-$ in the second stage of the tests

zależy od rodzaju gruntu i w znacznej mierze od zawartości wody w jego porach. Natomiast reaktancja stanowi część urojoną impedancji. Niezerowa wartość reaktancji powoduje przesunięcie fazowe (różnicę faz) pomiędzy natężeniem a napięciem prądu elektrycznego w obwodzie. Reaktancja charakteryzuje zmiany w gruncie spowodowane zróżnicowaniem jego uziarnienia czy też porowatości (Parilkova, Gombos, Talt i Kandra, 2009).

Do rejestracji pomiarów przewodności gruntu wbudowanego w model nasypu zastosowano urządzenie Z-Meter (rys. 3), w którym wykorzystano metodę pomiaru polegającą na porównaniu zmierzonej impedancji $(Z)$ o normalnej rezystancji $(R)$ ze znaną wartością oporu elektrycznego. Z-Meter umożliwia dużą dokładność i powtarzalność pomiarów oraz pełni również funkcję konsoli służącej do sterowania pomiarem. Przed pomiarem właściwym ustalono częstotliwość sygnału pomiarowego, a więc dokonano kalibracji tego sygnału. Wyniki pomiarów opracowano za pomocą arkusza kalkulacyjnego Excel.

Określono również zależność pomiędzy wilgotnością objętościową gruntu a jego rezystancją. Badania te wykonano w cylindrze do oznaczania wskaźnika nośności CBR o objętości 3,2 $\mathrm{dm}^{3}$. W cylindrze formowano próbki przy różnej wilgotności gruntu, ale do uzy- skania tej samej gęstości objętościowej szkieletu co w modelu nasypu. W próbce umieszczano elektrody pomiarowe i wykonywano pomiar rezystancji gruntu. Dla określenia wartości rezystancji gruntu w stanie pełnego nasycenia jego próbkę zalano wodą i przez kilkanaście godzin rejestrowano zmiany. Za wartość rezystancji odpowiadająca pełnemu nasyceniu gruntu przyjęto jej najmniejszą wartość otrzymaną w trakcie pomiarów.

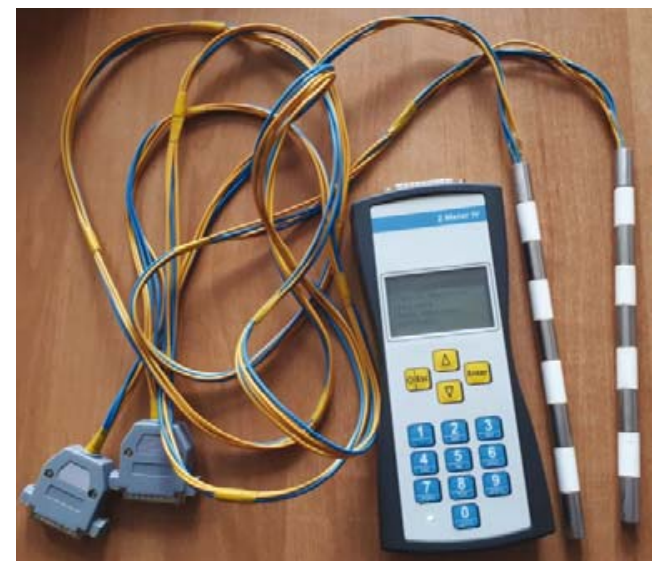

Rys. 3. Widok aparatu Z-Meter IV oraz elektrod pomiarowych EIS (fot. A. Gruchot)

Fig. 3. View of Z-Meter IV and EIS probes (photo A. Gruchot) 
Gruchot, A., Zydroń, T., Pařilková, J., Zachoval, Z., Cholewa, M. i Koś. K. (2018). Wykorzystanie spektrometrii impedancyjnej do monitorowania przepływu filtracyjnego przez nasypy hydrotechniczne. Acta Sci. Pol. Architectura, 17 (1), 55-65. doi: 10.22630/ ASPA.2018.17.1.6

Pomiary rezystancji gruntu wbudowanego w model nasypu przeprowadzono z wykorzystaniem dwóch, 5-kanałowych elektrod pomiarowych EIS długości $22,5 \mathrm{~cm}$ (rys. 3). Elektrody umieszczono w przekroju poprzecznym koryta $\mathrm{w}$ rozstawie $20 \mathrm{~cm}$ (rys. 4 i 5) w odległości $10 \mathrm{~cm}$ od piezometru P4 (rys. 1). Elektrody pomiarowe tworzyły $\mathrm{w}$ parze sondę pomiarową z 5 pionowymi segmentami pomiarowymi wysokości $2,5 \mathrm{~cm}$ każdy (odcinki przewodzące prą) rozmieszczonymi w odległości co $2,5 \mathrm{~cm}$. Elektrody swobodnie osadzono w nasypie w wywierconych otworach, nieznacznie większych od ich średnicy. Następnie otwory zasypano drobnoziarnistym piaskiem.

Wykonano również obliczenia przepływu nieustalonego przez model nasypu metodą elementów skończonych w programie Geo5. Modelowanie przepły-

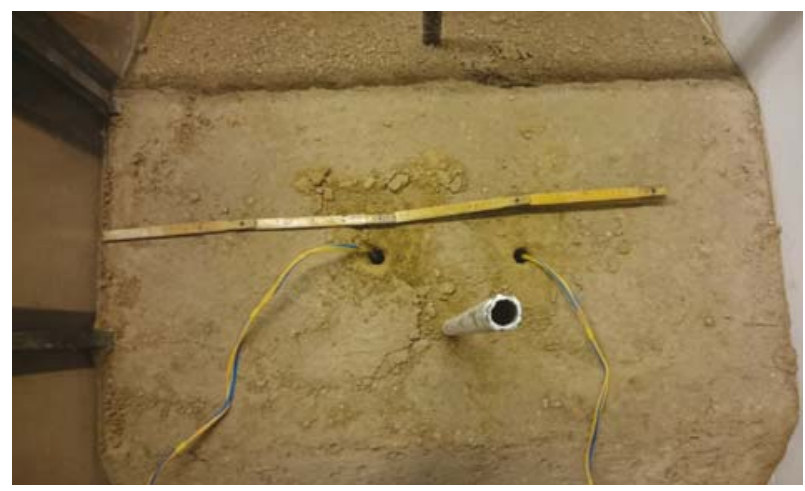

Rys. 4. Widok korony modelu obwałowania w trakcie instalowania elektrod pomiarowych EIS (fot. A. Gruchot)

Fig. 4. View of the top of the embankment model during installation of the EIS probes (photo A. Gruchot) wów filtracyjnych metodą elementów skończonych w ziemnych budowlach hydrotechnicznych pozwala w wiarygodny sposób ocenić wpływ tych zjawisk na prace takiej konstrukcji (Skutnik, 2013). Obliczenia miały na celu porównanie położenia krzywej filtracji $\mathrm{z}$ bezpośrednich pomiarów piezometrycznych oraz rezystancji gruntu z obliczeniami teoretycznymi. Założono zwiększenie poziomu wody od strony odwodnej od 0 do $0,5 \mathrm{~m}$, a przebieg krzywej filtracji wraz z rozkładem ciśnień porowych obliczono po $0,5,1,4$ i 7 dobach, co było zgodne z początkowym czasem badania w pierwszym ich etapie (rys. 2a). Obliczenia wykonano $\mathrm{z}$ podziałem modelu obliczeniowego na siatkę o długości krawędzi elementu 0,05 m, składającą się z 581 węzłów i 1035 elementów: 647 powierzchniowych, 97 belkowych i 291 kontaktowych (rys. 6).

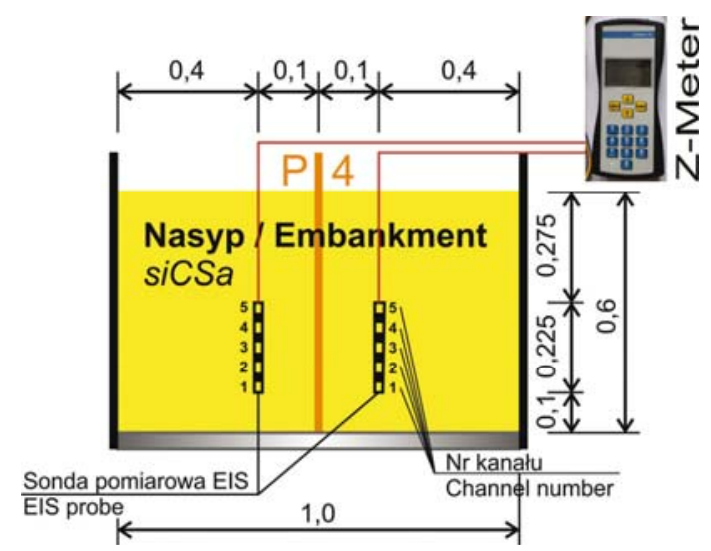

Rys. 5. Przekrój modelu obwałowania z lokalizacją elektrod pomiarowych w pobliżu piezometru P4 (wymiary $\mathrm{w} \mathrm{m}$ )

Fig. 5. The cross section of the embankment model with localization of EIS probes next to piezometer P4 (dimensions in $\mathrm{m}$ )

Rys. 6. Dyskretyzacja modelu nasypu obwałowania uzyskana w programie Geo5

Fig. 6. Discretisation of the embankment model from Geo5 software

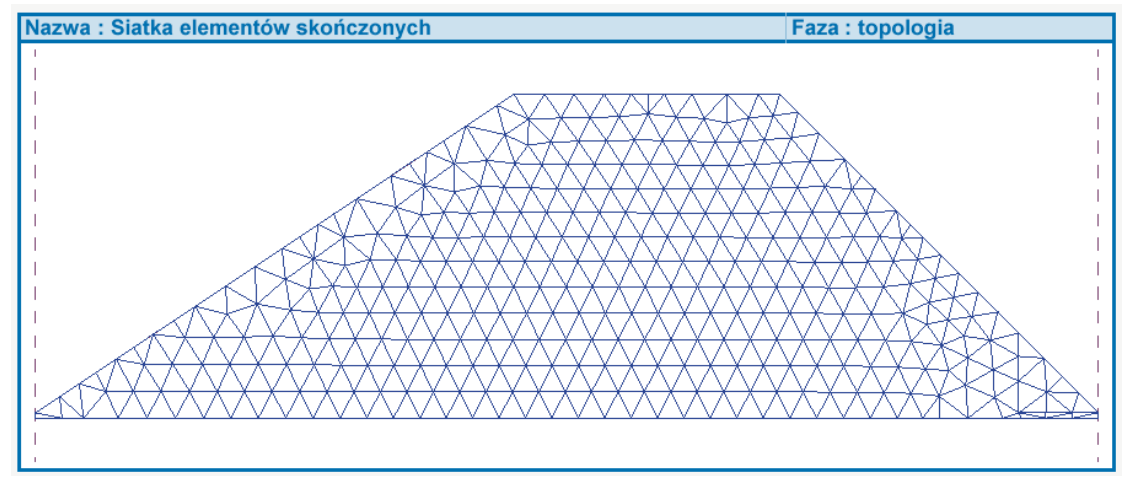


Gruchot, A., Zydroń, T., Pařilková, J., Zachoval, Z., Cholewa, M. i Koś. K. (2018). Wykorzystanie spektrometrii impedancyjnej do monitorowania przepływu filtracyjnego przez nasypy hydrotechniczne. Acta Sci. Pol. Architectura, 17 (1), 55-65. doi: 10.22630/ ASPA.2018.17.1.6

Obliczenia przeprowadzono według równania ciagłości cieczy Richardsa, zakładając brak odkształcalności szkieletu. Do obliczeń przepływu wody w strefie częściowego nasycenia parametry gruntu opisano równaniem Van Genuchtena (1980). Parametry retencyjne gruntu określono na podstawie uziarnienia gruntu, stosując zmodyfikowany model Kovacs (Aubertin, Mbonimpa, Bussiere i Chapuis, 2003), następnie wykorzystując program RETC określono parametry równania Van Genuchtena, które wynosiły $\alpha=0,76395 \mathrm{~m}^{-1}$ i $n=3,16794$.

\section{WYNIKI BADAŃ}

\section{Właściwości fizyczne gruntu}

Zgodnie z nomenklaturą geotechniczną (PN-EN ISO 14688-2:2006) analizowany grunt sklasyfikowano jako kilkufrakcyjny, dobrze uziarniony piasek gruby pylasty (rys. 7, tab. 1). Wilgotność optymalna wynosiła blisko $8 \%$, natomiast maksymalna gęstość objętościowa szkieletu $-2,12 \mathrm{~g} \cdot \mathrm{cm}^{-3}$. Wartość współczynnika filtracji rzędu $10^{-8} \mathrm{~m} \cdot \mathrm{s}^{-1}$ pozwoliła zakwalifikować badany grunt do mało przepuszczalnych.

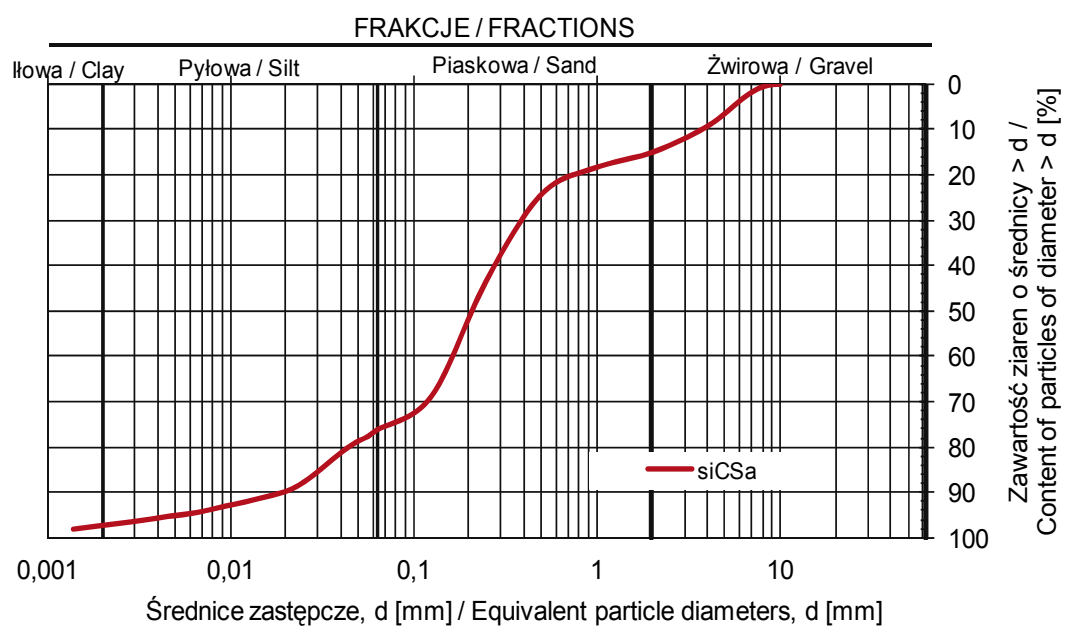

Rys. 7. Krzywa uziarnienia gruntu modelu nasypu

Fig. 7. Grain size distribution of the soil of the embankment model

Tabela 1. Charakterystyka geotechniczna gruntu modelu nasypu obwałowania

Table 1. Geotechnical characteristics of the soil of the embankment model

\begin{tabular}{|c|c|}
\hline Parametr - Parameter & Wartość - Value \\
\hline $\begin{array}{l}\text { Zawartość frakcji - Fraction content }[\%] \text { : } \\
\text { - żwirowa - gravel, Gr } 63-2 \mathrm{~mm} \\
\text { - piaskowa - sand, Sa } 2-0,063 \mathrm{~mm} \\
\text { - pyłowa - silt, Si } 0,063-0,002 \mathrm{~mm} \\
\text { - iłowa - clay, } \mathrm{Cl}<0,002 \mathrm{~mm}\end{array}$ & $\begin{array}{c}15,0 \\
61,0 \\
21,1 \\
2,9\end{array}$ \\
\hline Nazwa wg - Name acc. to PN-EN ISO 14688-2:2006 & $\begin{array}{l}\text { piasek gruby pylasty } \\
\text { silty coarse sand (siCSa) }\end{array}$ \\
\hline Wskaźnik różnoziarnistości - Uniformity coefficient [-] & 15,1 \\
\hline Wskaźnik krzywizny uziarnienia - Coefficient of curvature [-] & 3,0 \\
\hline Gęstość właściwa - Density of solid particles $\left[\mathrm{g} \cdot \mathrm{cm}^{-3}\right]$ & 2,71 \\
\hline Maksymalna gęstość objętościowa szkieletu - Maximum dry density of solid particles $\left[\mathrm{g} \cdot \mathrm{cm}^{-3}\right]$ & 2,12 \\
\hline Wilgotność optymalna - Optimum moisture content [\%] & 7,8 \\
\hline Współczynnik filtracji - Permeablity coefficient $\left[\mathrm{m} \cdot \mathrm{m}^{-1}\right]$ & $1,37 \cdot 10^{-8}$ \\
\hline
\end{tabular}




\section{Kalibracja elektrod pomiarowych}

Badania $\mathrm{z}$ zastosowaniem metody EIS wymagaja pomiarów kalibracyjnych rezystancji gruntu w odniesieniu do badanego ośrodka gruntowego. W prezentowanych badaniach kalibracje przeprowadzono w zakresie częstotliwości sygnału pomiarowego od 1000 do $10000 \mathrm{~Hz}$, stosując gradację co $25 \mathrm{~Hz}$ (rys. 8). Celem kalibracji było określenie częstotliwości pomiaru rezystancji najbardziej wrażliwej na zmiany wilgotności gruntu. Pomiary wykonano po zainstalowaniu elektrod pomiarowych w nasypie

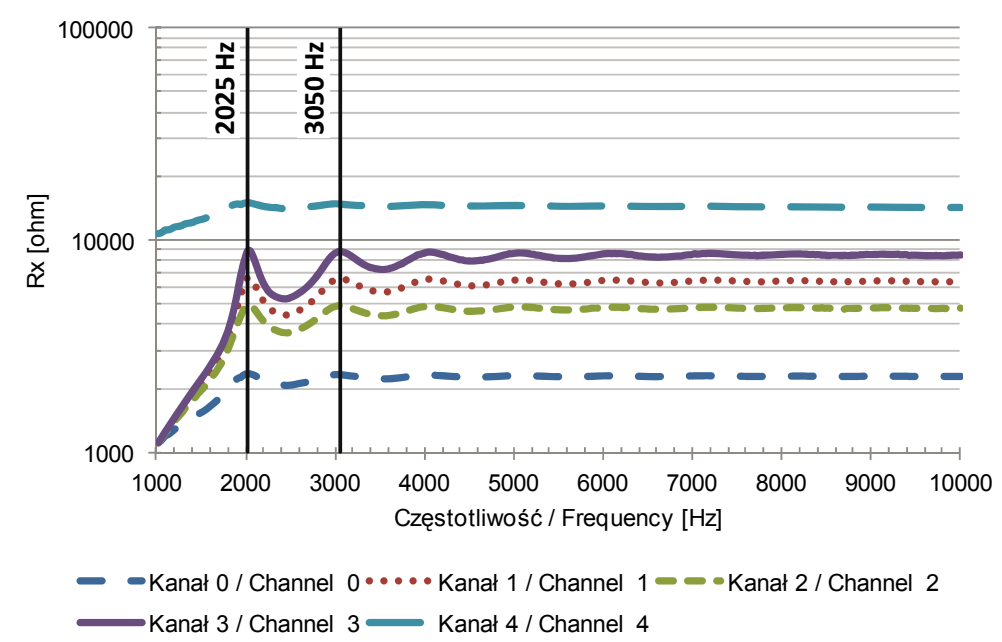

Rys. 8. Zależność rezystancji gruntu modelu nasypu od częstotliwości

Fig. 8. The soil resistance versus frequency

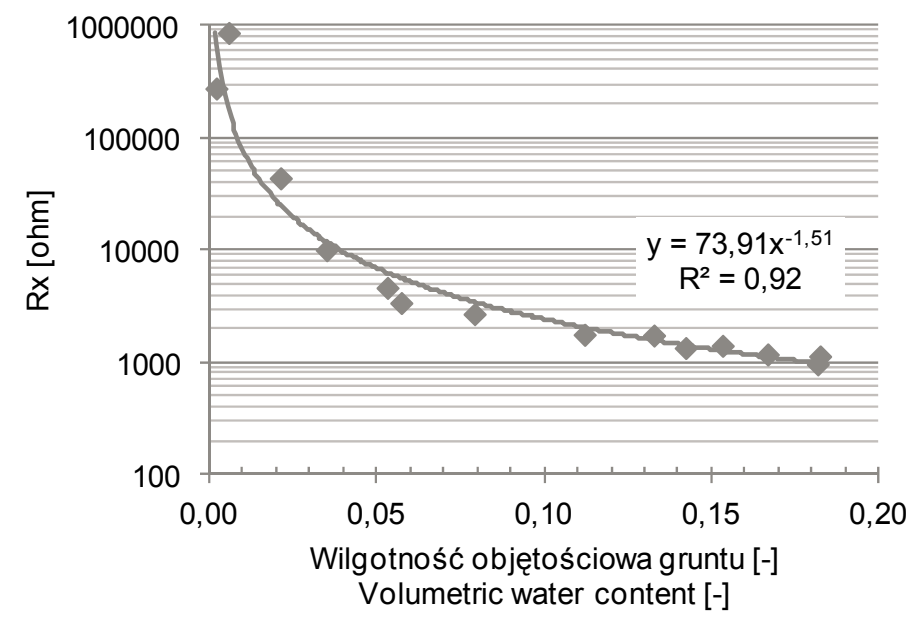

Rys. 9. Zależność rezystancji gruntu od jego wilgotności objętościowej

Fig. 9. The soil resistance versus volumetric water content i wykazały one, że największe zmiany wartości rezystancji uzyskano dla częstotliwości sygnału $2025 \mathrm{~Hz}$, a nieco mniejsze dla częstotliwości $3050 \mathrm{~Hz}$. Dlatego obydwie częstotliwości przyjęto do dalszych badań, natomiast analizę uzyskanych wyników przeprowadzono dla częstotliwości $2025 \mathrm{~Hz}$.

\section{Wpływ wilgotności na rezystancję gruntu}

$\mathrm{Na}$ etapie prac wstępnych określono zależność pomiędzy wilgotnością objętościową gruntu a jego rezystancją. Na rysunku 9 przedstawiono zależność badanych parametrów, przy czym pominięto wyniki uzyskane z kilkugodzinnych pomiarów próbki poddanej całkowitemu zalaniu woda, dla której minimalna wartość rezystancji kształtowała się nieco ponad $900 \Omega$. Ogólnie można stwierdzić, że otrzymana zależność jest dobrze skorelowana $\left(\mathrm{R}^{2}=0,92\right)$, co jest zgodne z wynikami badań Pařilkovej (Pařilkova $i$ in., 2009).

\section{Przepływ wody filtracyjnej}

W pierwszym etapie badań zmiany poziomu wody filtracyjnej były spowodowane podnoszeniem i obniżaniem zwierciadła wody od strony skarpy odwodnej. Natomiast w drugim etapie zmiany te wynikały ze zmian wysokości zwierciadła wody $\mathrm{z}$ obydwu stron nasypu.

Porównując wyniki pomiarów wysokości zwierciadła wody w piezometrze P4 i rezystancji z sond pomiarowych zainstalowanych w pobliżu tego piezometru, stwierdzono dobrą zależność zmian pomierzonych parametrów (rys. 10 i 11). Zwiększenie poziomu zwierciadła wody $\mathrm{w}$ piezometrze było istotnie związane ze zmniejszaniem się wartości rezystancji ośrodka gruntowego, natomiast wraz z obniżaniem poziomu wody następowało zwiększanie rezystancji gruntu. Najmniejsze 
Gruchot, A., Zydroń, T., Pařilková, J., Zachoval, Z., Cholewa, M. i Koś. K. (2018). Wykorzystanie spektrometrii impedancyjnej do monitorowania przepływu filtracyjnego przez nasypy hydrotechniczne. Acta Sci. Pol. Architectura, 17 (1), 55-65. doi: 10.22630/ ASPA.2018.17.1.6

wartości rezystencji zarejestrowano na kanale 0 , usytuowanym $10 \mathrm{~cm}$ nad podłożem nieprzepuszczalnym nasypu, a wartości rezystancji zarejestrowane na pozostałych kanałach wzrastały stopniowo wraz z wysokością ich położenia, co świadczyło o różnym stopniu nasycenia gruntu w tej części nasypu.

Uzyskane wyniki pomiarów po 7 dobach (168 godzin pomiaru) wskazują, że woda w piezometrze $\mathrm{P} 4$ znajdowała się nieco ponad $20 \mathrm{~cm}$ nad podstawą nasypu (rys. 10a), a wartości rezystancji zarejestrowane na głębokościach $10 \mathrm{~cm}$ (kanał 0), $15 \mathrm{~cm}$ (kanał 1) i $20 \mathrm{~cm}$ (kanał 2) mieściły się w zakresie od 1000 do $1400 \Omega$ (rys. 10b), co wydaje się odpowiadać wartości oporności gruntu bliskiemu pełnemu nasyceniu (por. rys. 9). Potwierdzają to wyniki pomiarów uzyskane w drugim etapie badań (rys. 11), pomiędzy 5. dobą (120. godzina) a 25. dobą (600. godzina) trwania pomiarów, kiedy to poziom wody od strony odwodnej i odpowietrznej był taki sam i wynosił $0,5 \mathrm{~m}$. Wartości rezystancji zarejestrowane $\mathrm{w}$ tym przedziale czasowym na każdym kanale pomiarowym były bardzo zbliżone i wynosiły około $1000 \Omega$ (rys. 9). Badania wstępne, w których wyznaczano zależność wilgotności objętościowej gruntu od jego rezystancji, wskazują, że dla gruntu nasyconego wartość rezystancji wynosiła nieco ponad $900 \Omega$. Z kolei poziom zwierciadła wody $\mathrm{w}$ piezometrze $\mathrm{P} 4 \mathrm{w}$ tym okresie układał się tuż poniżej lub powyżej wysokości położenia najwyższego segmentu pomiarowego (kanał 4-30 cm od podstawy modelu). Zauważalne
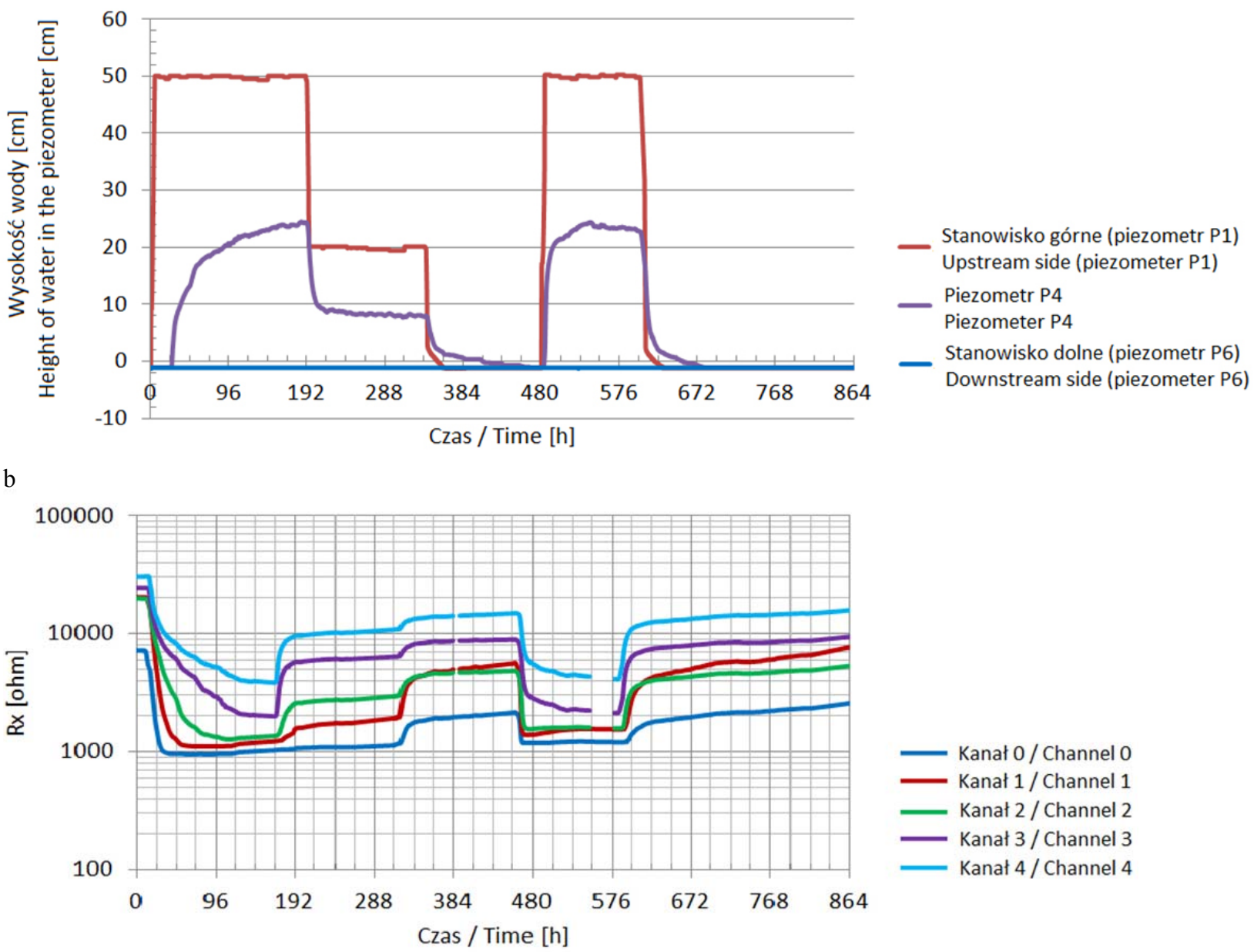

Rys. 10. Zmiany wysokości wody (a) i rezystancji gruntu (b) w pierwszym etapie badań

Fig. 10. Water height (a) and soil resistance (b) changes at the first stage of the test 
Gruchot, A., Zydroń, T., Pařilková, J., Zachoval, Z., Cholewa, M. i Koś. K. (2018). Wykorzystanie spektrometrii impedancyjnej do monitorowania przepływu filtracyjnego przez nasypy hydrotechniczne. Acta Sci. Pol. Architectura, 17 (1), 55-65. doi: 10.22630/ ASPA.2018.17.1.6

a

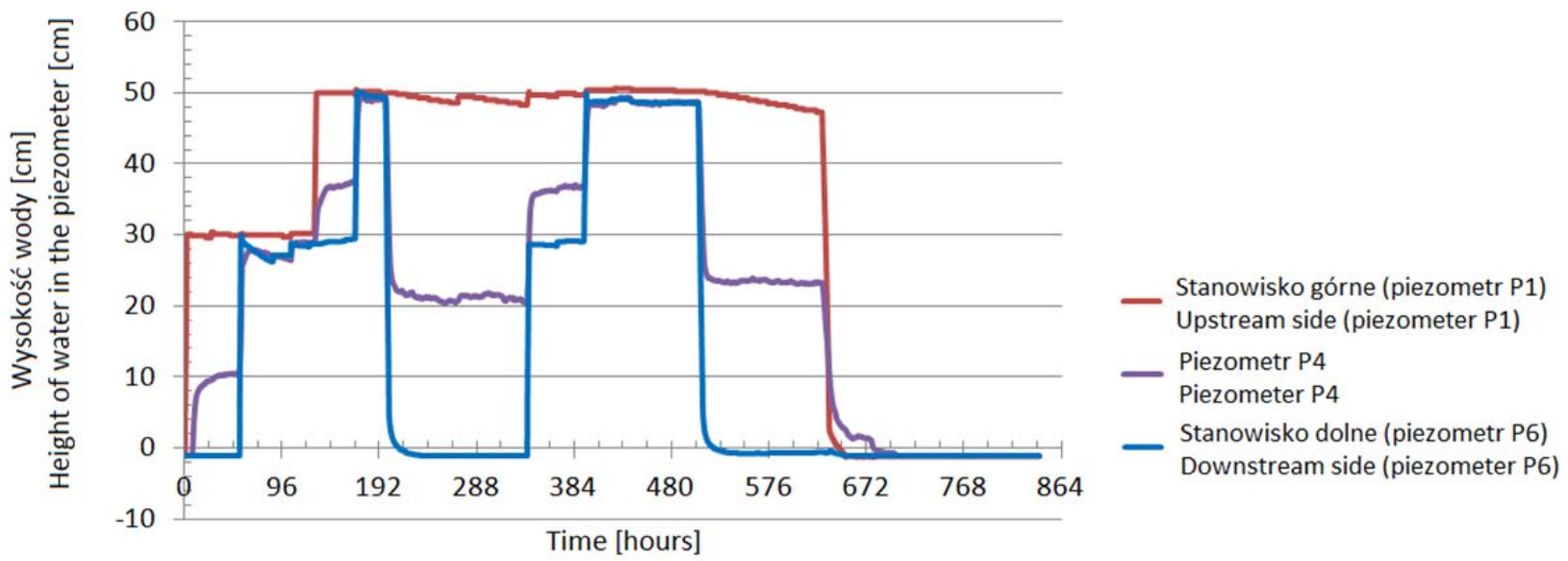

b

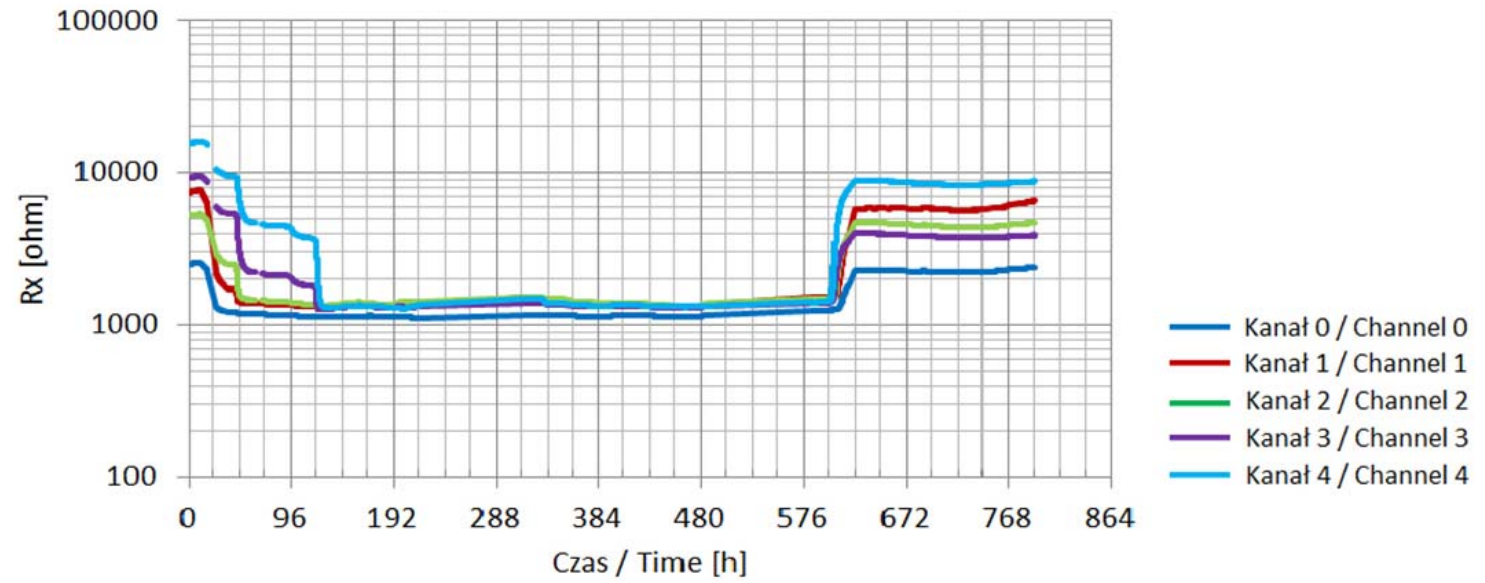

Rys. 11. Zmiany wysokości wody (a) i rezystancji gruntu (b) w drugim etapie badań

Fig. 11. Water height (a) and soil resistance (b) changes at the second stage of the test

jest, że w drugim etapie pomiędzy 8. a 14. dobą badania (192. a 366. godziną) występował nieznaczny wzrost rezystancji gruntu spowodowany prawdopodobnie zmniejszeniem się jego wilgotności. Podobne zjawiska zaobserwowano również pomiędzy 21 . a 27. dobą badania (504. a 648. godziną). W tym czasie poziom zwierciadła wody w piezometrze uległ obniżeniu do wysokości poniżej $32 \mathrm{~cm}$, a więc układał się w obszarze najwyżej położonego segmentu pomiarowego (kanał 4). Należy jednak zwrócić uwage, że zmiany rezystancji w obydwu okresach pomiarowych były bardzo niewielkie i były prawdopodobnie związane z przemieszczaniem się strefy podsiąku kapilarnego.

\section{OBLICZENIA PRZEPEYWU NIEUSTALONEGO}

Na rysunku 12 przedstawiono wyniki obliczeń filtracyjnych, które porównano z wynikami pomiarów piezometrycznych (rys. 10a-piezometr P4). Stwierdzono, że przeprowadzone obliczenia przepływu nieustalonego metodą elementów skończonych wykazały dobrą zgodność $\mathrm{z}$ wykonanymi pomiarami w piezometrach w czasie 7 dób od zwiększenia poziomu wody w korycie hydraulicznym od 0,0 do $0,5 \mathrm{~m}$. Na rysunku 12 przedstawiono przebieg krzywej filtracji oraz zmiany ciśnienia porowego po $0,5,1,4$ i 7 dobach w nasypie doświadczalnym, ustalone na podstawie wykonanych obliczeń. Natomiast na rysunku 13 pokazano przebieg 
a $\quad t=0,5$ doby - day

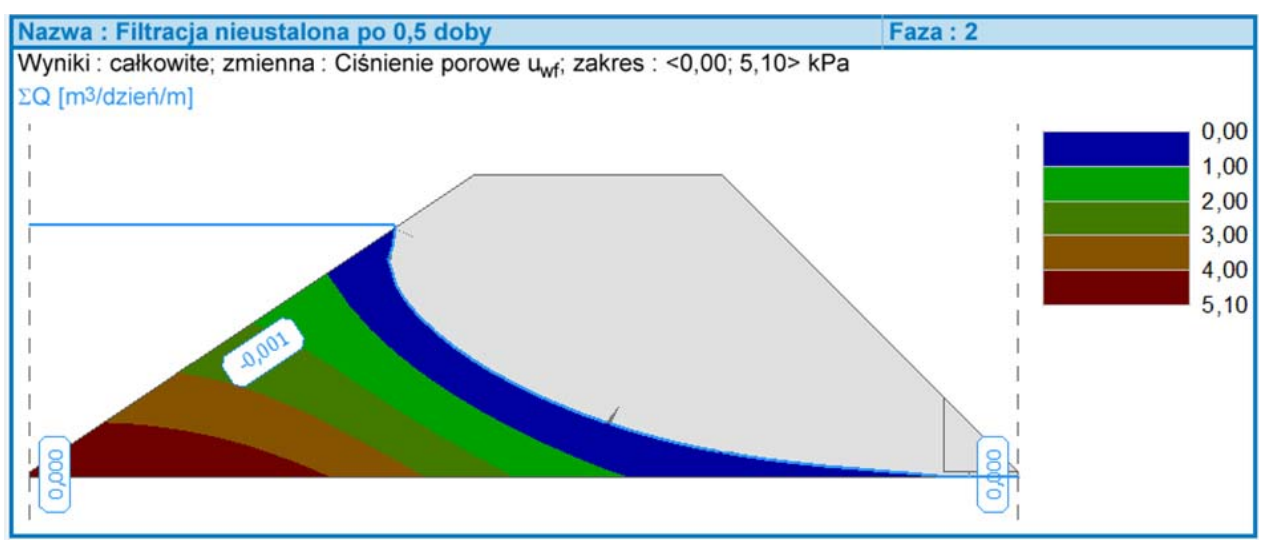

b $\quad t=1$. doba - day

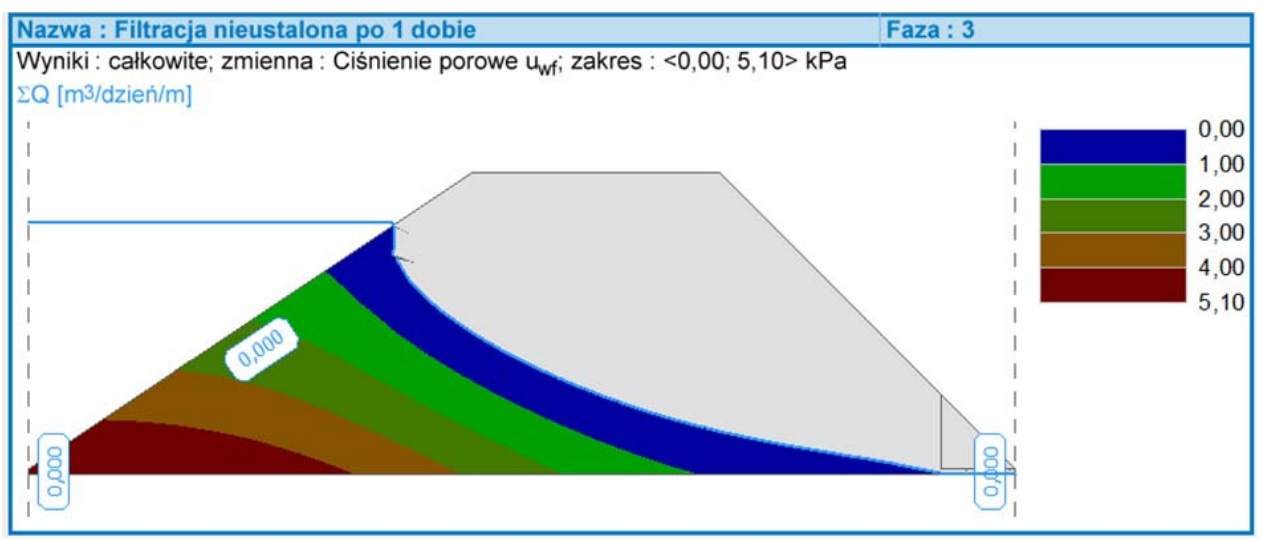

c $t=3$. doba - days

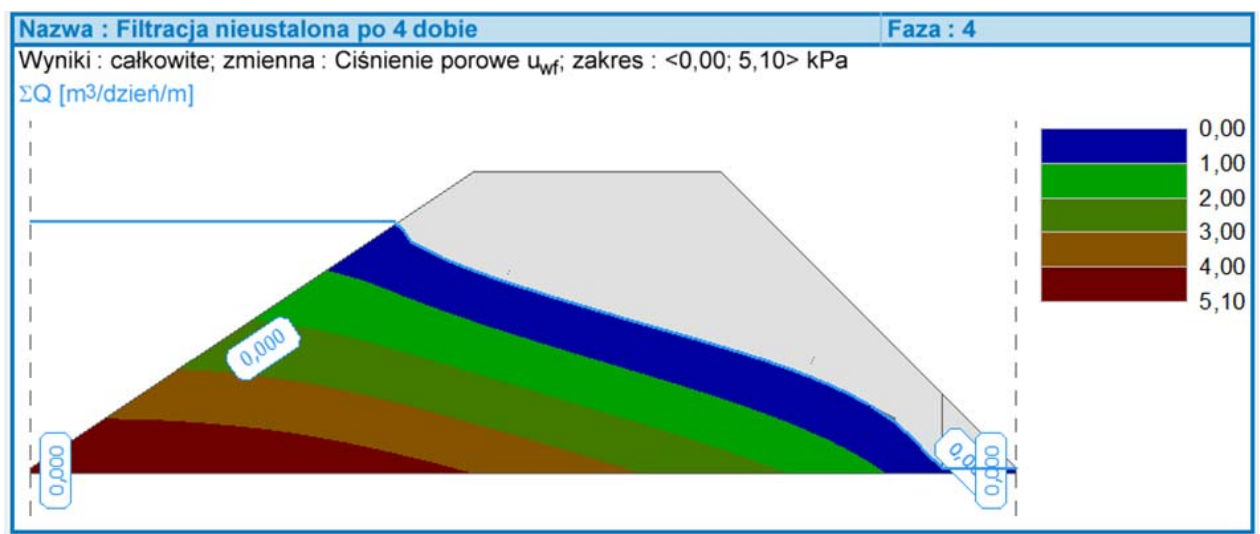

d $\quad t=7$. doba - days

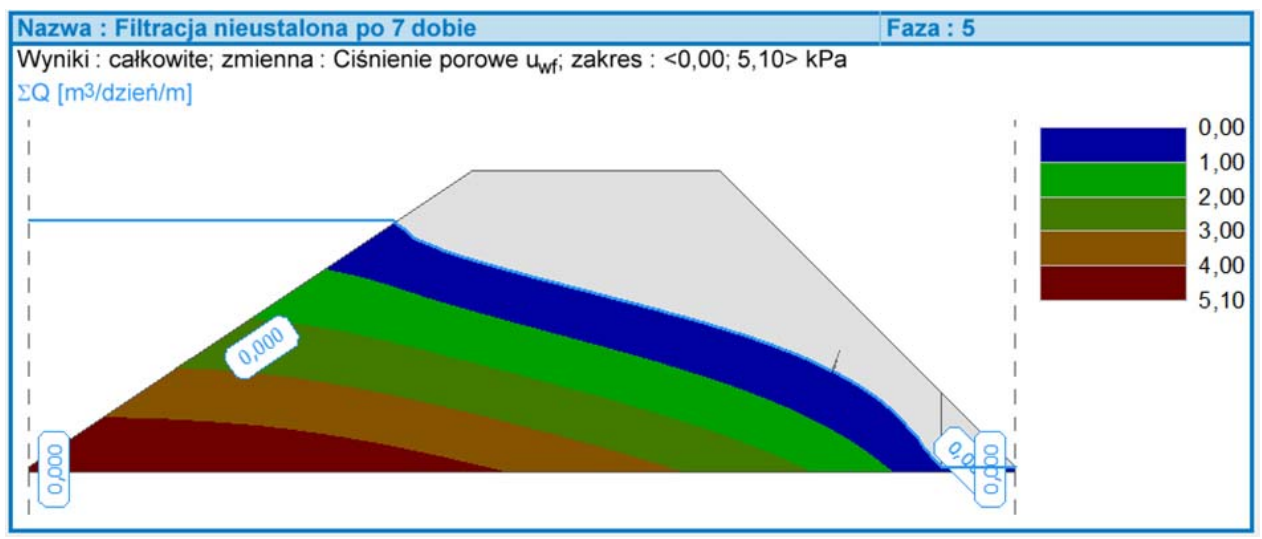

Rys. 12. Przebieg granicy nasycenia (krzywej filtracji) wraz ze zmianami ciśnienia porowego w warunkach filtracji nieustalonej przez model nasypu uzyskanej z programu Geo5

Fig. 12. Course of the saturation limit (filtration curve) along with changes in the pore pressure at the conditions of unsteady filtration through the embankment model, obtained from Geo5 program 


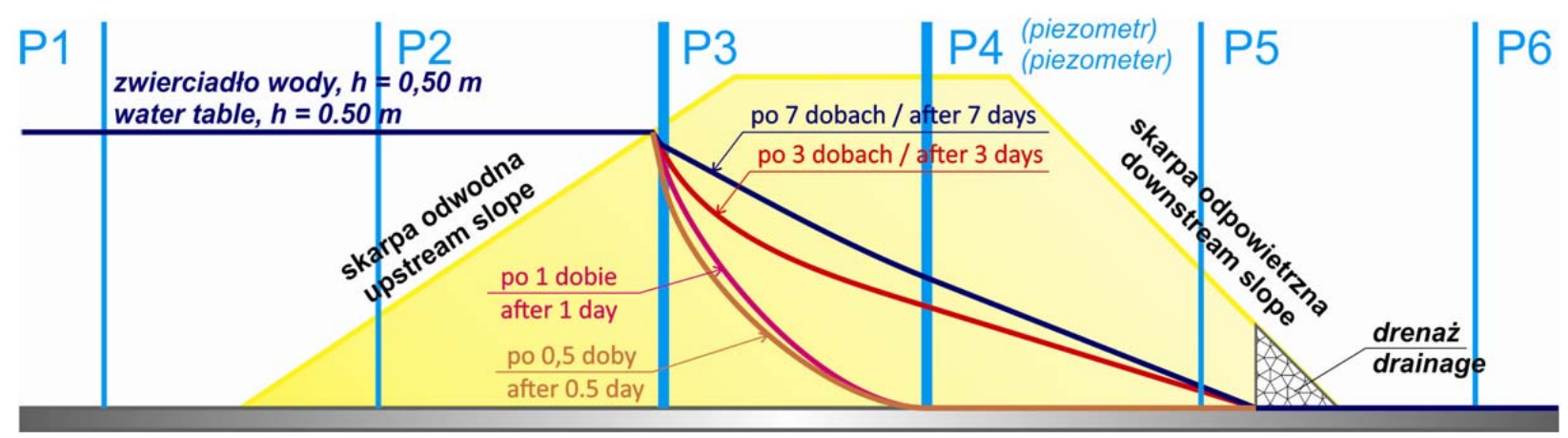

Rys. 13. Przebieg krzywej filtracji ustalony na podstawie pomiarów poziomu wody w piezometrach P3 i P4

Fig. 13. The filtration curve determined based on the measurement of the height of the water in piezometer P3 and $\mathrm{P} 4$

krzywej filtracji z pomiarów bezpośrednich poziomów wody filtracyjnej w piezometrze P3 i P4.

Największe różnice w wysokości przebiegu krzywej filtracji pomiędzy obliczeniami a wartościami pomierzonymi stwierdzono $\mathrm{w}$ początkowym etapie badań (po 0,5 doby i 1 . dobie), występowały one głównie w linii piezometru P4. Natomiast po 3 i 7 dobach różnice te były niewielkie, co świadczy o dobrej zgodności obliczeń teoretycznych z pomiarem wysokości wody w piezometrze. Stwierdzone różnice wynikają najprawdopodobniej $\mathrm{z}$ zaniżonych wartości współczynnika filtracji, którego wartość oznaczono dla materiału o uziarnieniu mniejszym od $4 \mathrm{~mm}$.

\section{PODSUMOWANIE}

Badania wykazały, że wyniki pomiarów rezystancji gruntu są istotnie skorelowane $\mathrm{z}$ wilgotnością objętościową gruntu, a więc metoda spektrometrii impedancyjnej może stanowić wiarygodne źródło obserwacji zjawisk filtracyjnych zachodzących $\mathrm{w}$ gruncie. Przeprowadzone badania potwierdziły dobra zbieżność wyników pomiarów piezometrycznych oraz obliczeń metodą elementów skończonych przebiegu krzywej filtracji w modelu nasypu z wynikami pomiarów rezystancji gruntu metodą spektrometrii impedancyjnej.

Można wskazać celowość stosowania metody spektrometrii impendacyjnej (EIS) do monitorowania zmian położenia zwierciadła wody filtracyjnej w obiektach ziemnych, jakimi są obwałowania cie- ków lub zapory ziemne. Należy jednak zauważyć, że metoda ta wymaga doboru właściwej częstotliwości sygnału pomiarowego, dostosowanej do rodzaju monitorowanego gruntu, którego skład uziarnienia i przewodność hydrauliczna może zmieniać się w dość szerokim zakresie w przekroju nasypu ziemnego. Należy również pamiętać, że metoda EIS ma charakter przybliżony i do właściwej interpretacji wyników pomiarów uzasadnione wydają się wstępne badania, mające na celu rozpoznanie zakresu spodziewanych wartości oporności elektrycznej gruntu i ich związku z jego wilgotnością.

\section{ADNOTACJA}

Praca wykonana w ramach projektu EUREKA! 7614, a także badań statutowych nr DS-3322/KIWiG/2017.

\section{PIŚMIENNICTWO}

Aubertin, M., Mbonimpa, M., Bussiere, B. i Chapuis, R.P. (2003). A model to predict the water retention curve from basic geotechnical properties. Canadian Geotechnical Journal, 40 (6), 1104-1122.

Bednarczyk, S., Bolt, A. i Mackiewicz, S. (2009). Stateczność oraz bezpieczeństwo jazów i zapór. Gdańsk: Wydawnictwo Politechniki Gdańskiej.

Chalfen, M. i Kamińska, J. (2011). Wpływ niedokładności określenia współczynnika filtracji elementów uszczelniających na warunki przepływu wody przez wały przeciwpowodziowe. Acta Scientiarum Polonorum, Architectura, $10(1), 5-17$. 
Gruchot, A., Zydroń, T., Pařilková, J., Zachoval, Z., Cholewa, M. i Koś. K. (2018). Wykorzystanie spektrometrii impedancyjnej do monitorowania przepływu filtracyjnego przez nasypy hydrotechniczne. Acta Sci. Pol. Architectura, 17 (1), 55-65. doi: 10.22630/ ASPA.2018.17.1.6

Gruchot, A., Zydroń, T., Cholewa, M. i Koś, K. (2016). Using impedance spectroscopy method (EIS) to monitor filtration - model tests. W $4^{\text {th }}$ Conference and Working Session within the Frame-work of the International Programme EUREKA, Project No. E!7614 (strony 82-90). Lednice, Czech Republic 13-14.10.2016 r.

Molski, T. (2010). Wpływ warunków filtracji naporowej na stateczność ziemnych budowli hydrotechnicznych i podłoża. Monografie. Wrocław: Uniwersytet Przyrodniczy.

Pařilková, J. i Pařilek, L. (2008). Monitoring of the Earth Dam of a Water Reservoir by the Method of Electrical Impedance Spectrometry. W Eureka 2008. $4^{\text {th }}$ Working Session Within the frame of the International Program EUREKA, Project No. E!3838 (strony 21-31). Research, Development and Processing of Computerized Measuring System of Soils Moisture with EIS Method. September 18-19, 2008, GEOtest Brno, Inc., Czech Republic.

Parilkova, J., Gombos, M., Talt, A. i Kandra, B. (2009). Calibration of Z-meter device for measurement of volumetric moisture of soils. W Eureka 2009. $5^{\text {th }}$ Working Session Within the frame of the International Program EUREKA, Project No. E!3838 (strony 21-31). Research, Development and Processing of Computerized Measuring System of Soils Moisture with EIS Method. November 11-13, 2009, Brno University of Technology, Brno, Czech Republic.

Pařilková, J. i Pařilek, L. (2015). Monitoring of the earth-fill dam of the Hornice reservoir monitored by EIS. W Eureka 2015. $3^{r d}$ Conference and Working Session Within the frame of the International Program EUREKA, Project No. E!7614 (strony 205-224). A System of Monitoring of Selected Parameters of Porous Substances Using the
EIS Method in a Wide Range of Applications. October $15^{\text {th }}-16^{\text {th }} 2015$, Jaromerice nad Rokytnou.

Pařilková, J., Zachoval, Z., Pařilek, L. i Frankova, H. (2015). The earth-fill dam of the Karolinka water reservoir monitored by the EIS method. W Eureka 2015. $3^{\text {rd }}$ Conference and Working Session Within the frame of the International Program EUREKA, Project No. E!7614 (strony 58-67). A System of Monitoring of Selected Parameters of Porous Substances Using the EIS Method in a Wide Range of Applications. October $15^{\text {th }}-16^{\text {th }} 2015$, Jaromerice nad Rokytnou.

Pisarczyk, S. (2001). Gruntoznawstwo inżynierskie. Warszawa: Wydawnictwo Naukowe PWN.

PN-EN ISO 14688-2:2006. Badania geotechniczne. Oznaczanie i klasyfikowanie gruntów. Część 2: Zasady klasyfikowania.

Skutnik, Z. (2013). Zastosowanie MES w projektowaniu geotechnicznym ziemnych budowli hydrotechnicznych. Przeglad Naukowy - Inżynieria i Ksztaltowanie Środowiska, 62, 511-520.

Van Genuchten, M.T. (1980). A closed form equation for predicting the hydraulic conductivity of unsaturated soils. Soil Science Society American Journal, 44, 892-898.

Yanev, Y., Farhi, O.A., Draganova, E.D. i Ionova, D. (2014). A study of the effect of temperature in measuring soil electrical resistance by the methofd of electroimpedance spectroscopy. W Eureka 2015. $2^{\text {rd }}$ Conference and Working Session Within the frame of the International Program EUREKA, Project No. E!7614 (strony 75-81). A System of Monitoring of Selected Parameters of Porous Substances Using the EIS Method in a Wide Range of Applications. October $30^{\text {th }}-31^{\text {th }} 2014$, Pasphlavky.

\title{
USE OF IMPEDANCE SPECTROMETRY FOR MONITORING FILTRATION FLOW THROUGH HYDROTECHNICAL EMBANKMENTS
}

\begin{abstract}
One of the most important problems in assessing the technical condition of earth hydrotechnical structures concerns the observation of the water filtration process and the analysis of the possibility of occurrence of unfavourable phenomena connected with it. The purpose of the study was to evaluate the usefulness of EIS (Electrical Impedance Spectroscopy) to observe the process of water filtration through the earth embankment body. The tests were carried out in a hydraulic channel on a model of the embankment made of silty coarse sand. The filtration flow was caused by multi-stage lifting and lowering the water level in the hydraulic channel. Measurements of soil resistivity values were referred to automatically registered piezometric water level. The obtained results showed significant convergence of changes in soil resistance due to the water flow with changes in the level of filtration water measured in the piezometer.
\end{abstract}

Key words: impedance spectrometry, filtration, earth structure 